\title{
PROMOTING ENVIRONMENTAL AWARENESS IN LEARNING CONTEXTS
}

\author{
Dirtya S. Paradewari, Anchieta A. Avillanova, and Aloysia B. Lasar \\ Sanata Dharma University Yogyakarta \\ gisellarin@gmail.com, anchieta.ave@gmail.com, and aloysia.lasar@gmail.com \\ DOI: https://doi.org/10.24071/ijhs.2018.010213
}

Received October 28, 2017; revised January 18, 2018; accepted February 4, 2018

\begin{abstract}
A bundle of studies in multidisciplinary context has been conducted concerning the earth changes. As we are now witnessing the destruction that our earth is suffering from, promoting environmental awareness becomes visible to be vital. In line with the rapid development of information mobility and technology, English is becoming world's language. The scope of English users then proved to be continuously in growth. Therefore, English as foreign language (EFL) learning context is considered ideal to promote the environmental awareness. There are some evidence that support the way of promoting the environmental awareness in the educational context. Moreover, Pike and Shelby (1994) point out consciousness in various aspects as the desired result for promoting environmental awareness through education. This paper elaborates those evidence and discusses the aims of global environmental education.
\end{abstract}

Keywords: narratology, physical structure, mental structure, semantic axis

\section{Introduction}

Our earth is now becoming brittle compared to decades ago. There are so many environmental issues which are facing by the human in this world as a consequence of the earth changes. Sovacool (2014) presents that there are four main environmental issues, namely: "climate change, air pollution, water availability and quality, and land-use change". Climate change becomes an egregious threat for all of the people around the world. However, there are still many people who are not aware of this issue and not realize that humans are changing the Earth's climate (Cicerone \& Nurse, 2014). Then, air pollution becomes the next issue that is concerned. "There are two kinds of air pollution, namely, indoor and outdoor air pollution”. Indoor air pollution can be caused by the heat of stoves used in the house. Besides, Sovacool (2004) states that "Outdoor air pollution is significantly caused by energy production and use as about $80 \%$ of sulfur dioxide emissions, $80 \%$ of particulate matter emissions and $70 \%$ of nitrogen oxide emissions come from the energy and transport sectors" ( $p$. 5). Water availability and quality turn into the third environmental issue. Water is now mostly contaminated because of household activity or commercial industry. 
This can be dangerous for all creatures since water becomes an important element in life. The last environmental issue is land-use change. Our forests are declining because of the needs of many companies which want to get advantages from the forest. Therefore, the forests now become quite far from the real function which it is known as lungs of the earth.

As environmental issues grow rapidly in today's life, people need to have the environmental awareness which can help the earth recover the existence. Environmental awareness is "an important factor in increasing sustainable behavior or practices and focuses on knowledge of the environmental concerns happening globally as well as strategies for positively impacting these concerns" (Gomez, et al., 2015, p. 357). It is vital for people to sustain natural beauty for some reasons, including tourisms (Yuniarto, 2017). Another factor is its tropical climate. Raising environmental awareness can be done by every person who is willing to keep and preserve this earth. Public education is one of the means. Through public education, ideas and relationship about environmental facts are transferred rather than isolated (Minkova, 2002). Points and meanings about the environment are the roots of the concern. Those aspects are expected to help many people understand and appreciate the environment.

In addition, people can learn about environment both formally and informally. Formally means they learn it from schools, while informally means that they learn about the environment through many things outside school's field. As an example of informal way, people can join an environmental organization or learn about the environment through the internet. In this paper, the researchers focus on promoting environmental awareness of the formal schools' students in EFL learning contexts. Some schools might have provided an environmental subject to raise students' awareness of the environment. However, other schools which have not provided that kind of subject in their schools can still promote students' awareness of the environment through other subjects, for example, English subject. Hadzigeorgiou and Skoumios (2013) state that "there is an argument to be raised in regard to the difficulty for students to develop environmental awareness, due to the difficulty they have to become involved with the natural world, as their object of study, in the first place" (p. 410). Therefore, taking into consideration the background above, English subject is chosen as a tool to promote students' environmental awareness easier.

The objective of this study is to present the importance of promoting environmental awareness in EFL learning contexts. Promoting environmental awareness in education is important because Hadzigeorgiou and Skoumios (2013, p. 405) assert that people can be more respect for the environment when they have more responsible behavior. Besides, the relationship between people and nature can also be changed through the development of environmental awareness. Furthermore, according to Hadzigeorgiou (2012, p. 987), as a prerequisite of learning, students have to be able to shift or change their perspective through awareness. Therefore, when students learn about environmental in the classroom, they are expected to have different yet better insights about earth and environment. 


\section{Theory}

Students learn both formally and informally, they learn in a school and outside of school. In a daily life, they learn natural environment. The natural environment can construct students' knowledge and experience. The teachers can give the students an assignment to present some environmental issues around them, therefore, it is called as a representational pedagogy. "Promoting environmental awareness is considered a crucial goal in the context of education" (Slattery, 2003; Slattery \& Rapp, 2003). The importance of this goal is in the interdependence between humankind and the world (Richards, 2001; Orr, 2003). The students may also use their own experience when they try to present the assignment and it is called the constructivist pedagogy (Biesta \& Osberg, 2007). Students have already learned some environmental issues but not all of them are truly conscious what they have learned. Learning process needs authenticity, therefore, the students are required to connect the task to their own experience in order to raise their environmental awareness.

Hadzigeorgiou (2012) suggests the as empirical evidence that awareness also facilitates "a shift or change in perspective, which is a prerequisite for significant learning". Some of the experts in education have an argument in the value of teaching in assisting students to develop a new perspective of a world (Jardine, Clifford \& Friesen, 2003, p. 102; Peters, 1973, p. 20; Schank, 2004, p. 37). The new perspective may lead students to see the new knowledge "in a coherent pattern of a life" (Peters, 1966, p. 45). However, the students cannot see the knowledge in a simple way. They should pick things which are appropriate to their own life. "To be educated is not to have arrived at a destination; it is to travel with a different view" (Peters, 1973, p. 20).

Environmental knowledge, attitudes, and actions connect with environmental awareness which has "an effect on students' attitudes" (Dimopoulos, Paraskevopoulos, \& Pantis, 2009). Besides that, critical thinking is also linked to environmental awareness (Wals, 2011). Therefore, the students who are aware of environmental issues may develop their critical thinking and build exemplary attitudes.

\section{Environmental Issues}

Sovacool (2014) explains four main issues in environmental awareness, as follows: Climate change is an important issue in environmental awareness. Grajal, Goldman, and Marks (2012, p.1) define climate change as "an observable phenomenon rooted in nearly two centuries of basic science." People experience the climate change in today's era. Students in a school also experience the climate change. To facilitate the students in understanding better the climate change, the teachers should raise their awareness by adding this phenomenon to the courses. Sovacool (2014) states that climate change has the big impacts to the world because it can decrease carbon dioxide (CO2) emissions. The climate change is caused by some factors. First, the concentrations of greenhouse gasses are caused the climate change (Grajal et al., 2012, p. 2). The greenhouse gasses and carbon dioxide $(\mathrm{CO} 2)$ have risen over the past two hundred and fifty years due to the combustion of fossil fuels. Second, the factors caused a climate change is a landuse change. It attributes to the quarter of carbon dioxide (CO2) emissions to the atmosphere. The third factor is sulfate aerosol and black carbon. Volcanic eruptions may produce a sulfate aerosol because it is a tiny airborne particle. 
Some industrial activity may also increase the concentrations of sulfur. Those factors may lead to the climate change. After knowing some factors, the students are expected to combat this phenomenon.

Considering the environmental awareness, air pollution is also the aspect of it. Air pollution can harm people if the concentrations in the atmosphere are high. "Air pollution may be harmful to the development of the brain and may affect cognitive ability" (Calderón-Garcidueñas et al., 2008; Suglia et al. 2008; Wang et al., 2009). McConnell et al. (2002) claim that pollution is associated with asthma "as well as other respiratory diseases, lower lung function, hay fever and infant mortality". Zweig, Ham, \& Avol (2009, p. 2) describe four mechanisms that affects students' academic performance. Four of the mechanisms are school absenteeism, attention problems, fatigue, and brain development. Therefore, the students should learn the effects of air pollution in a classroom.

Water is the important elements in daily life. People need it to wash, drink, take a bath, and much more. The supply of water must consider the availability and quality of the water itself. "Groundwater is the primary source of water" (Dennehy et al., 2004). Alley et al. (1999) describe a groundwater sustainability is the "development and use of groundwater in a manner that can be maintained for an indefinite time without causing unacceptable environmental, economic, or social consequences". In schools or outside of school such as a house, the students need water, therefore, to recognize the water availability and quality are necessary things to do.

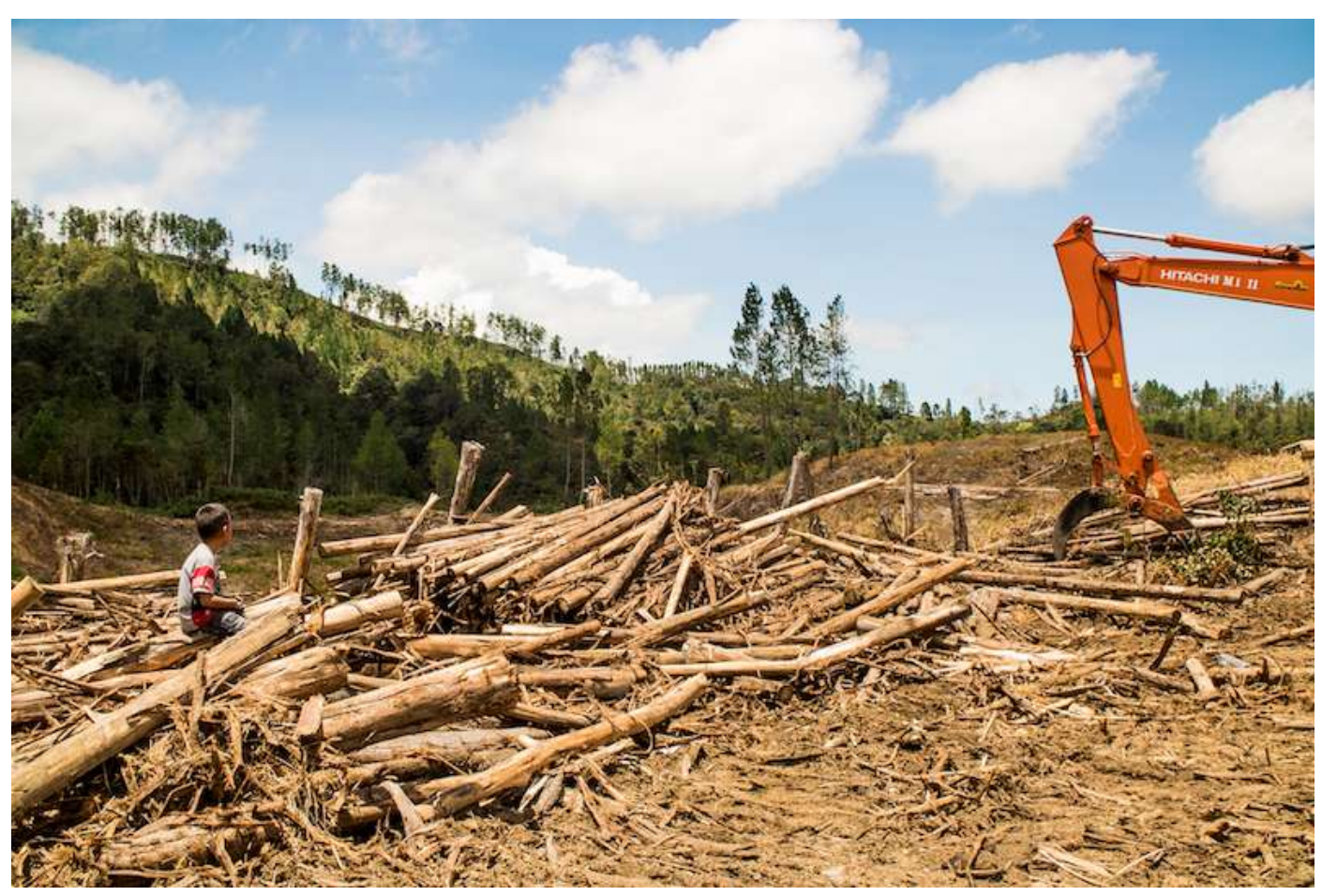

Figure 1. Land exploitation (source: www.ran.org) 
Morara, MacOpiyo, and Kogi-Makau (2014, p. 192) describe that the aims of which people exploit the land is land use. The land-use change includes demographic changes, economic changes, policies, and quality changes and access to services and infrastructure (Olson, 2006; Bebe et al., 2012; Mwangi, 2006). The land-use may affect the air pollution. In this case of urban changes will affect human beings in undergoing this life. Therefore people should build their own desire to prevent this environmental issues.

\section{Theory Application}

\section{Implementation of Promoting Environmental Awareness}

Regarding the unpleasant effects that we may hear as the prophecy of our future earth, environmental awareness needs to be taken into account as a concern of all. People are campaigning everywhere. Industries and companies are competing to produce environmental friendly stuff. However, the effort of preserving our earth has been started even more than three decades ago. Early in 1972, "the United Nations first put forward the idea of "sustainable development" in its first Conference on the Human Environment, emphasizing that any development must take into account the environment, balancing not only economic and social needs but also the needs of future generations.

In the early 1990s, the United Nations also worked with the World Bank to construct the System of Integrated Environmental and Economic Accounting to promote the calculation of green national income" (United Nations, 1993). In Asia, Hong Kong government launched a strategic study entitled "Sustainable Development for the 21st Century in Hong Kong" in 1998 and established the Council for Sustainable Development the next year to plan the long-term development of environmental affairs in Hong Kong. In wider contexts, environmental awareness is gained through policies, regulations, organizations and community. While in education, the real action should be well-structured and functioned practicality.

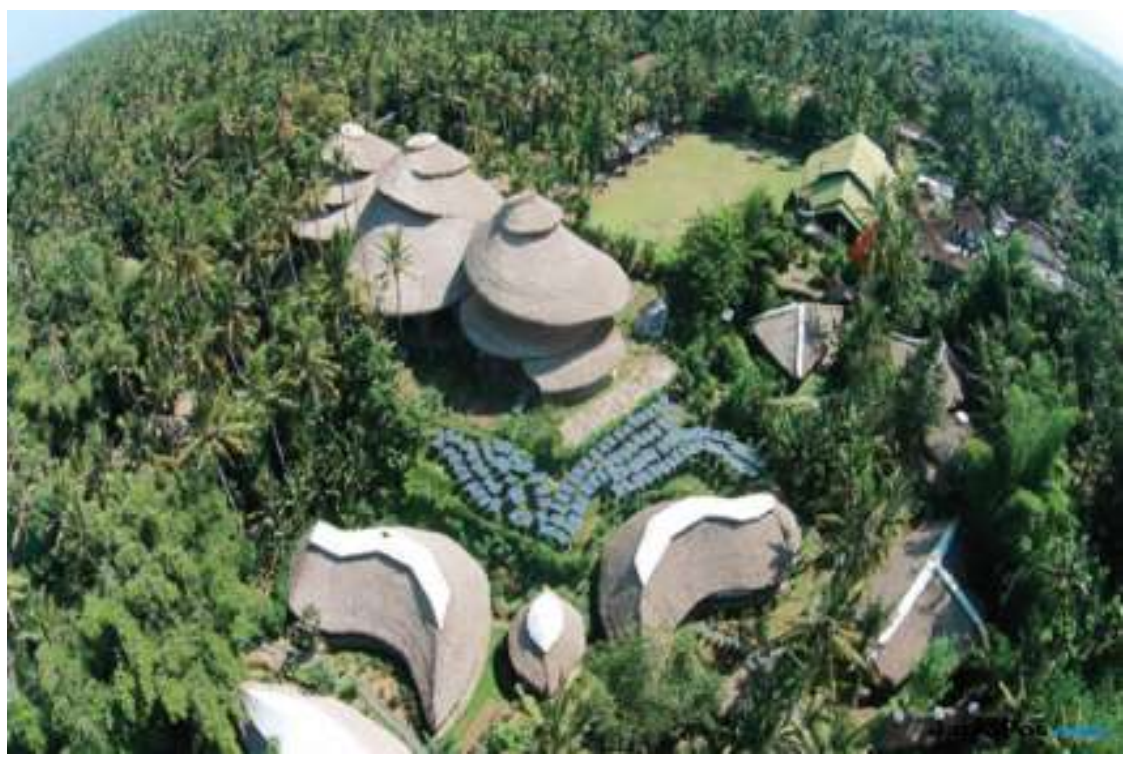

Figure 2. Green school (source: www.jawapos.com) 
Recently, people start to initiate green schools, also some are to implement environmental-based curriculum in their schools. One of them which is the best we can find in Indonesia is "Green School Bali, a non-profit, private and international pre-kindergarten to high school". They integrated nature and students-centered approach in learning. They provide facilities and learning environment that vote for earth sustainability. They have enrolled school not only for children from abroad but also for children from Indonesia (www.greenschool.org). This becomes visible as a great step of preserving earth through education.

\section{Teaching Environmental Issues in EFL Learning Context}

The main environmental issues are climate change, air pollution, water availability and quality, and land-use change. Considering these issues, EFL learners should learn how to minimize the effects of that. Tang (2009) says that teaching environmental education may raise students' awareness about the crises of global environmental. Students who have a critical thinking may think about the project that they can do to save the world for the global environmental crises. Cates (1997) notices that "We cannot call our English teaching successfully if our students, however fluent, are ignorant of word problems, have no social conscience by using their communication skills for international crime, exploitation, oppression, or environmental destruction". Brown (1991) adds that teachers are the agent of change to help students do something for this environmental issues, particularly English teacher. English teachers have an important role to be the agent of change because the language ability they have, it means that the teachers can share the knowledge not only in the country where they live but also other countries.

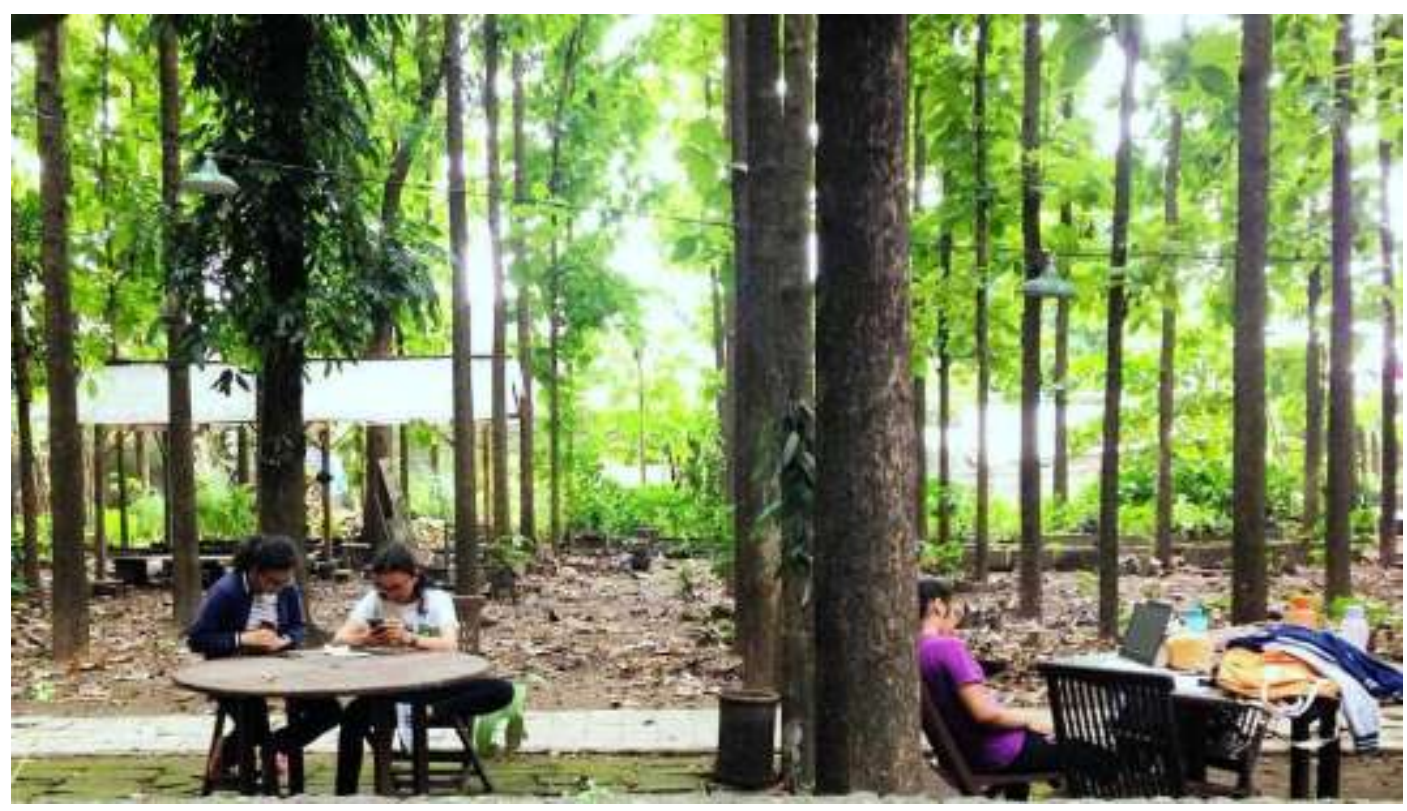

Figure 3. Sanata Dharma's Centre for Environmental Studies (source: www.usd.ac.id) 
Pike and Shelby (1994, p. 301) divide five aims for global environmental education. The first is system consciousness in which students should gain the thinking ability "in a system mode, an understanding of the systemic nature, and a holistic conception of their potential". The second is perspective consciousness in which students are able to discern that the worldview they have is not shared universally and they should build receptivity to other perspectives. The third is the health of planet awareness in which students should acquire the global environmental issues and trends. The fourth is involvement consciousness and preparedness in which students have the choice to choose what the best for this world is and the choice they make, have repercussions for the global nowadays. The last is process mindedness in which students should learn and build a personal development to see the world is vibrant but dangerous. These aims for global environmental may be used by the teachers to make an absorbing teachinglearning process in a classroom. Since the environmental issues can be linked to subjects in a school, it can be the bridge the gap between language teaching and other subjects. Furthermore, the major international English teachers' associations such as Teaching English to Speakers of Other Languages (TESOL) and International Association for Teachers of English as Foreign Language (IATEFL) have established sections focusing on environmental issues.

Regarding teaching environmental issues in EFL learning contexts, English teachers should not be confused because Veselinovska and Kirova (2013, p. 1067) suggest four materials that can be used in the classroom in the context of environmental education. The first is that students can bring any articles, audio, video, newspaper, magazine, radio, TV shows, or the internet. Pudhika (2016) the use of The Toughest Place to be a Binman video, a video to raise students' awareness, gives the students meaningful experiences. Furthermore, after watching The Toughest Place to be a Binman video, the students are expected to be more aware of the environment around the students, especially the trash.

The second, the students can make use of song which contains environmental elements in the lyric. The third is by having a conversation about the latest environmental issues. The fourth, the students and their classmates can develop surveys regarding the environmental issues. Through those four kinds of materials, the students are expected to develop their environmental awareness through critical thinking. Veselinovska and Kirova (2013, p. 1068) express that students will be able to enhance their abilities for critical thinking as well as they develop their language skill through "the inclusion of environmental education in English language teaching". Therefore, the teachers should use the materials wisely and creatively so that the students can develop their critical thinking well.

\section{Conclusion}

The evidence which is provided here can be the way to promote environmental awareness to the EFL learners. The students should be familiar with the environmental issue because it is important nowadays. If they are not aware of the environmental issues then who will be aware of that? Since they are the next generations who will continue to undergo this precious life. Yet if students are not aware of environmental issues, they will be regret in the future. The young generations will not experience the good atmosphere to live. 
Teachers as the facilitator in a classroom should teach the environmental issues to raise environmental awareness to the students. Cates (1990) says that the way teachers teach is important because the students do not have time to sit silently learning. It is the time for students to explore and learn their environment because the environment is a part of the world they live. Particularly for those students who can speak different languages such as the English language, they can share to friends from other countries about their experience living in this environment. Since learning a language is not only learning its structure but also how to use it in delivering the message and communicating to others.

\section{References}

Alley, W. M., Reilly, T. E., \& Franke, O. E. (1999). Sustainability of groundwater resources. U.S. Geological Survey Circular 1186, 79.

Bebe, B. O., Lagat, J. K., Magembe, E. M. (2012). Evaluation of the factors associated with shift from pastoral to agro-pastoral farming systems in Trans-Mara West District of Narok County-Kenya. Asian J. Agr. Sci, 4(6):403-410.

Biesta, G., \& Osberg, D. (2007). Beyond representation: A case for updating the epistemology of schooling. Interchange, 38, 15-29.

Brown, H. D. (1991). 50 Simple things you can do to teach environmental awareness and action in your English language classroom. The Language Teacher, 15, 4-5.

Calderón-Garcidueñas, L., Mora-Tiscareño, A., Ontiveros, E., Gómez-Garza, G., Barragán-Mejía, G., Broadway, J., Chapman, S., Valencia-Salazar, G., Jewells, V., Maronpot, R.R., Henríquez-Roldán, C., Pérez-Guillé, B., Torres-Jardón, R., Herrit, L., Brooks, D., Osnaya-Brizuela, N., Monroy, M. E., González-Maciel, A., Reynoso-Robles, R., Villarreal-Calderon, R., Solt, A. C., \& Engle, R. W. (2008). Air pollution, cognitive deficits and brain abnormalities: A pilot study with children and dogs. Brain Cognition, 68, 117-127.

Cates, K. A. (1997). New trends in global issues and English teaching. The Language Teacher Online, 21(5). Retrieved December 11, 2016 from http://jalt-publications.org/tlt/files/96/nov/global.html

Cicerone, R. J., \& Nurse, S. P. (2014). Climate change evidence \& causes. Washington: National Academy of Sciences.

Dennehy, K. F., McMahon, P. B., Gurdak, J. J., \& Bruce, B. W. (2004). Water quality and the availability and sustainability of water supplies in the high plains aquifer: Water-quality assessment of the high plains aquifer. Professional Paper 1749, 107-136.

Dimopoulos, D., Paraskevolpoulos, S. \& Pantis, J. (2009). Planning educational activities and teaching strategies on constructing a conservation educational module. International Journal of Environmental and Science Education, 4, 351-364.

Gomez, J. M., Sonnenschein, M., Vogel, U., Winter, A., Rapp, B., \& Giesen, N. (2015). Advances and new trends in environmental and energy informatics: Selected and extended contributions from the 28th international conference on informatics for environmental protection. Cham: Springer. 
Grajal, A., Goldman, S. R., \& Marks, T. (2012). Climate change education: A primer for zoos and aquariums. Illinois: Chicago Zoological Society.

Hadzigeorgiou, Y. (2012). Fostering a sense of wonder in the science classroom. Research in Science Education, 42, 985-1005.

Hadzigeorgiou, Y., \& Skoumios, M. (2013). The development of environmental awareness through school science: Problems and possibilities. International Journal of Environmental \& Science Education, 8, 405-426

Hadzigeorgiou, Y., Klassen, S., \& Klassen -Froese, C. (2012). Encouraging a 'romantic under-standing' of science: The effect of the Nikola Tesla story. Science \& Education, 21, 1111-1138.

Jardine, D., Clifford, P., \& Friesen, S. (2003). Back to the basics of teaching and learning. Mahwah, NJ: Lawrence Erlbaum.

McConnell, R., Berhane, K., Gilliland, F., Islam T., Gauderman, W. J., Avol, E., Margolis, H., and Peters, J. (2002). Asthma in exercising children exposed to ozone:A cohort study. Lancet, 359, 386-91.

Minkova, Y. (2002). Public education to raise environmental awareness. Szentendre: The Regional Environmental Center for Central and Eastern Europe.

Morara, M. K., MacOpiyo, L., \& Kogi-Makau, W. (2014). Land use, land cover change in urban pastoral interface: A case of Kajiado County. Journal of Geography and Regional Planning, 7(9), 192-202.

Mwangi, E. (2006). Sub-dividing the commons: The politics of property rights transformation in Kenya's Maasailand. Environment and Production Technology Division. CAPRi Working Paper, 46.

Olson JM (2006). Implications of trends in land use change for livestock systems evolution in East Africa: Lessons from the LUCID Project. Discussion Paper No. 4 (Draft). Targeting and Innovations Discussion. Nairobi, Kenya: International Livestock Research Institute.

Orr, D. (2003). The constitution of nature. Conservation Biology, 17, 1473-1884.

Peters, R. (1966). Ethics and education. London: Allen and Unwin.

Peters, R. (1973). Aims of education: A conceptual enquiry. Oxford: Oxford University Press.

Phudika, M. P. (2016). Students' lived experience on The Toughest Place to be a Binman in Critical Listening and Speaking 1 Class. LLT Journal: A Journal on Language and Language Teaching, 19(2), 115-124. Retrieved from http://e-journal.usd.ac.id/index.php/LLT/article/view/305/260

Pike, G., \& Shelby, D. (1994). Globální výchova. Praha: Portál.

Richards, R. (2001). A new aesthetic for environmental awareness: Chaos theory, the beauty of nature, and our broader humanistic identity. Journal of Humanistic Psychology, 41(2), 59-95

Schank, R. (2004). Making minds less well educated than our own. Mahwah, NJ: Lawrence Erlbaum.

Slattery, P. (1995). Curriculum development in the postmodern era. New York: Garland.

Slattery, P., \& Rapp, D. (2003). Ethics and the foundation of education. Boston: Allyn \& Bacon.

Sovacool, B. K. (2014). Environmental issues, climate changes, and energy security in developing Asia. Manila: Asian Development Bank. 
Suglia, S. F., Gryparis, A., Wright, R. O., Schwartz, J., \& Wright, R. J. (2008). Association of black carbon with cognition among children in a prospective birth cohort study. American Journal of Epidemiology, 167, 280-286.

Tang, Y. C. (2009). The preliminary study for incorporating environmental education English curriculum and teaching. Dahan: Dahan Institute of Technology.

Veselinovska, S., \& Kirova. (2013). Blending the teaching of environmental matters and English as a second or foreign language in Macedonia. Natura Montenegrina, 12(3-4), 1065-1071.

Wals, A. (2011). Learning our way to sustainability. Journal of Education for Sustainable Development, 5, 177-186.

Wang, S. Q., Zhang, J. L., Zeng, X. D., Zeng, Y. M.,Wang, S. C., and Chen, S. Y. (2009). Association of traffic-related air pollution with children's neurobehavioral functions in Quanzhou, China. Environmental Health Perspectives, 117, 1612-1618.

Wong, T. K. \& Wan, S. P. (2008). Environmental awareness and behavior in Hong Kong: a decade of development. TASPAA Partnership with the International Conference on Sustainable Development.

Yuniarto, H. (2017). Promoting Indonesian tourism to Chinese tourists through journalism strategies in Wechat. International Journal of Humanity Studies, 1(1), 103-110 Retrieved from http://ejournal.usd.ac.id/index.php/IJHS/article/view/679/538

Zweig, J. S., Ham, J. C., \& Avol, E. L. (2009). Air pollution and academic performance: Evidence from California schools. National Institute of Environmental Health Sciences, 1-35.piyo, L., Kogi-Makau, W. (2014). Land use, land cover change in urban pastoral interface: A case of Kajiado County, Kenya. Journal of Geography and Regional Planning, 7(9), 192202. 